\title{
ESTRATÉGIAS DE CAMPO E DE LABORATÓRIO UTILIZADAS NA INVESTIGAÇÃO DO SÍTIO ARQUEOLÓGICO PEDRA DO CANTAGALO I
}

\section{Heralda Kelis Sousa Bezerra da Silva ${ }^{1}$ Luis Carlos Duarte Cavalcante ${ }^{2}$}

Resumo: A Pedra do Cantagalo I é um sítio arqueológico localizado no povoado Jardim, município de Piripiri, Piauí, Brasil. Consiste em um abrigo sob-rocha arenítica, cujas saliências e reentrâncias estão decoradas com mais de 1950 pinturas rupestres representando figuras abstratas, propulsores de dardos, carimbos de mãos humanas, antropomorfos e zoomorfos, realizados em padrões policromáticos. Além da elevada densidade de inscrições pré-históricas e da policromia, esse sítio também se destaca pela recorrência dos motivos pintados e pela sobreposição deles entre si. Nas plataformas e no piso rochosos do abrigo encontram-se dezenas de gravuras rupestres e de pilões. Nos sedimentos superficiais foram evidenciados fragmentos cerâmicos, líticos e ocres. Neste trabalho são reportadas as estratégias analíticas de campo e de laboratório utilizadas na investigação desse importante sítio arqueológico e dos testemunhos de atividade humana pré-históricos nele existentes ou dele coletados. Os exames físicos, a caracterização químico-mineralógica dos materiais, o monitoramento das condições ambientais e as prospeç̧ões no entorno foram primordiais.

Palavras-chave: Pintura rupestre; Gravura rupestre; Cerâmica; Lítico; Ocre; Arqueologia.

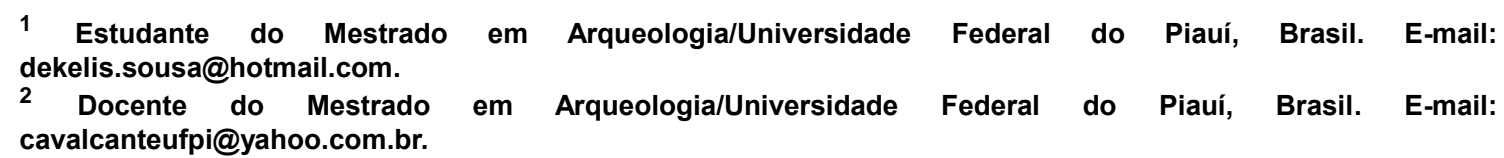

